\title{
O grafite e sua ressignificação: linha tênue entre 0 vandalismo e a arte de rua
}

\author{
Graffiti and re-signification: a thin line between vandalism and street \\ art
}

CASTRO, Andrea Carolina Camargo

Pontifícia Universidade Católica do Rio de Janeiro - PUC-Rio

andreaccamargoc@gmail.com

GAMBA JUNIOR, Nilton Gonçalves

Pontifícia Universidade Católica do Rio de Janeiro - PUC-Rio

gambajunior@gmail.com

\begin{abstract}
Resumo
O artigo faz parte do processo da dissertação de mestrado, que pretende analisar a diversidade de práticas contemporâneas do grafite na cidade do Rio de Janeiro. Aqui são discutidas duas dimensões dentro do universo do grafite: a sua função comercial e a legislação que rege a prática dentro do Brasil. O estudo destaca parte de uma amostra da pesquisa que ilustrará um método de classificação proposto a partir da variedade de aplicações do grafite, considerando a legislação nacional vigente.
\end{abstract}

Palavras Chave: Grafite. Espaço urbano. Arte de rua.

\section{Abstract}

This paper reports on a research project for a master's degree. It analyzes the diversity of contemporary graffiti practices in the city of Rio de Janeiro. The study focuses on two key dimensions: on the one hand, the graffiti and its commercial outcomes; and on the other, the current legislation about street art in Brazil. We highlight part of the research sample to support a classification method on the variety of graffiti practices, with respect to the national legislation.

Keywords: Graffiti. Urban space. Street art. 


\section{INTRODUC̣ÃO}

A estética das grandes cidades é composta por inúmeros elementos que interagem com a sua população. A arquitetura, o transporte, os passantes e tantos outros elementos e fenômenos compõem a paisagem da cidade. Associados a eles, encontramos grafites e pichações, que são pintados em muros e fachadas e contribuem com o visual do espaço público citadinos.

A origem do grafite é remontada às antigas inscrições feitas em paredes. Alguns escritos feitos no espaço público têm seus registros mais antigos datados de 85-95 d.C., no antigo Império Romano, por exemplo, alguns cidadãos escreviam em latim vulgar diversas mensagens como pensamentos políticos, insultos, declarações de amor. Os arqueólogos chamaram essas intervenções com o termo graffiti, (do plural graffito que, em italiano, significa rabisco). Mas foi só a partir do século XX, durante os anos 70, nos Estados Unidos, que a prática de pintar mensagens e desenhos nas ruas foi potencializada e tornou-se uma forma de expressão para representar e defender os ideais de grupos e gangues. A tendência apropriou-se do termo/nome usado na arqueologia (graffiti, grafite em português) e espalhou-se rapidamente pelos muros da cidade, criando visuais com mensagens e imagens em espaços públicos a céu aberto. Desde então, até hoje, o grafite faz parte da paisagem urbana em inúmeros lugares do mundo.

Assim, o grafite apareceu como um meio para manifestar opiniões de caráter político e, em pouco tempo, passou a ser usado como elemento expressivo da cultura urbana do Hip-Hop. Em ambos os casos, a intenção dos grupos era a de expressar inconformidades com o poder público, fazendo um ato de posicionamento e de contestação, sem violência física, mas não sem confrontos simbólicos. O grafite se consolida como uma forma de comunicação direta entre quem faz e quem observa e pode-se dizer que cada região ou artista desenvolve seu estilo particular.

O grafite no Brasil, influenciado por Nova lorque, iniciou-se como uma forma de comunicação que defende a liberdade de expressão e representa os mais variados propósitos: marca registrada de um único indivíduo; opiniões de índole política; divulgação de publicidade ou simplesmente um ato decorativo. A cidade de São Paulo marca o início do grafite brasileiro com o artista precursor Rui Amaral. Rui descreve esse início da seguinte maneira:

Nos idos dos anos 80 eu e mais um grupo de artistas começamos a fazer intervenções urbanas de forma ilegal na cidade, vivíamos uma ditadura, onde não havia diálogo com o poder público, nascia o grafite brasileiro. Realizamos várias intervenções que viraram marco do movimento do Grafite paulistano como o Beco do Batman, o bairro da 


\begin{abstract}
Vila Madalena o Minhocão e o complexo viário Paulista com Dr. Arnaldo ou 'Buraco da Paulista' [...] havia uma área especifica para artistas que trabalhavam a cidade como suporte, foi nesta época que começamos a dar início ao projeto de revitalização do 'Buraco da Paulista', [...] o maior marco das intervenções urbanas paulistanas, especificamente o grafite. (AMARAL, 2014)
\end{abstract}

No Rio de Janeiro, o grafite também tem construído sua história. Na antiga capital carioca, a pintura urbana também começou a ser usada como meio de manifestação política e social. De lá pra cá, tem se diversificado como em outros lugares do mundo, ampliando o leque de finalidades e estéticas, multiplicando as formas e linguagens. Nesse artigo, apresentamos alguns casos destacados no espaço urbano da capital fluminense, no intuito não só de analisar como o grafite se mostra na paisagem urbana carioca hoje, mas também, de refletir sobre a atual relação dessa arte com a legalidade e os fins comerciais.

\title{
2 A LEGISLAC̣ÃO SOBRE $O$ GRAFITE
}

A ação de pintar os muros e a sua legitimação como forma de expressão têm colocado em debate as mais diversas opiniões a favor da prática e contra ela, criando questionamentos e divergências. No Brasil, há uma diferenciação na classificação legal e no senso comum sobre a intervenção com tinta em espaços públicos, segundo diversos aspectos da composição final da imagem, de suas funções mais evidentes, do local onde está e do processo pelo qual ela foi realizada. A classificação envolve incialmente a distinção entre a pichação e o grafite: o primeiro define a prática de escrever em muros, edifícios, monumentos e vias públicas, sem autorização, o que faz com que seja visto como um gesto de vandalismo. Já o grafite é considerado como uma prática artística, cuja execução autorizada ou contratada por entidades públicas e privadas é mais bem aceita e frequentemente reconhecida e classificada como arte de rua.

A pichação é considerada um crime e o grafite uma arte, mas, na verdade, os limites não estão bem definidos para cada circunstância e cada caso depende do ponto de vista de quem observa - o que é picho? o que é grafite?

Num esforço por estabelecer critérios mais claros para determinar a legalidade do exercício, o governo tem se manifestado, criando leis e decretos que tentam definir os limites sobre a aplicação do grafite e suas variantes. No Brasil temos a Lei no 9.605 Seção IV - Dos Crimes contra o Ordenamento Urbano e o Patrimônio Cultural - de 12 de fevereiro de 1998 (BRASIL, 1998) 
que distingue os dois registros (de crime ou legalidade) pelo ato de conspurcar (causar danos) de um lado, ou de valorizar um patrimônio:

Art. 65. Pichar ou por outro meio conspurcar edificação ou monumento urbano: (Redação dada pela Lei no 12.408, de 2011) - Pena - detenção, de 3 (três) meses a 1 (um) ano, e multa. (Redação dada pela Lei no 12.408, de 2011)

$\S 10$ Se o ato for realizado em monumento ou coisa tombada em virtude do seu valor artístico, arqueológico ou histórico, a pena é de 6 (seis) meses a 1 (um) ano de detenção e multa. (Renumerado do parágrafo único pela Lei no 12.408, de 2011)

§ 20 Não constitui crime a prática de grafite realizada com o objetivo de valorizar o patrimônio público ou privado mediante manifestação artística, desde que consentida pelo proprietário e, quando couber, pelo locatário ou arrendatário do bem privado e, no caso de bem público, com a autorização do órgão competente e a observância das posturas municipais e das normas editadas pelos órgãos governamentais responsáveis pela preservação e conservação do patrimônio histórico e artístico nacional. (Incluído pela Lei no 12.408, de 2011). (BRASIL, 2011).

Algumas cidades brasileiras têm estipulado decretos e leis para seu território, no entanto as polêmicas sobre o grafite na gestão do Prefeito João Dória em São Paulo são um caso exemplar de visibilidade e complexidade das questões. No caso específico de Rio de Janeiro, a prefeitura se abriu ao diálogo com artistas de rua e grafiteiros, num esforço de estabelecer critérios para a prática. Em fevereiro de 2014, Eduardo Paes, então prefeito do Rio de Janeiro, assinou o decreto GrafiteRio, junto com a criação do Conselho Carioca do Grafite, para atuar como um canal de articulação entre o poder público e esta manifestação cultural. No decreto, foi proposta a intervenção em espaços públicos com alto potencial turístico para serem revitalizados com arte (chamados de Células de Revitalização), o apoio ao site StreetArtRio e a instituição do Dia do Grafite em 27 de março (em homenagem a Alex Vallaury, artista plástico e grafiteiro, pioneiro do grafite na cidade de São Paulo), que passa a fazer parte do Calendário Oficial de Datas e Eventos da cidade (DAVID, 2014).

O projeto de Lei № 268 de 2013, decretado pela Câmara Municipal do Rio de Janeiro e proposto pelos vereadores Chiquinho Brazão e Marcelo Arar, dispõe regras sobre a arte com grafite no âmbito do Município do Rio de Janeiro, legitimando as ações do Projeto Grafite estimulado pelo poder público: a utilização dos espaços públicos para a prática do grafite com autorização realizada através da Secretaria Municipal de Cultura; a realização de grafites em áreas privadas, com autorização expressa por parte do proprietário; a premiação de obras de grafite na rede pública de educação, através de comissão 
julgadora formada por alunos da rede pública de ensino, professores da rede pública, artistas plásticos, urbanistas, paisagistas e arquitetos; e a preservação e proteção de obras de grafite, por parte do Poder Público. (RIO DE JANEIRO, 2013).

O prefeito para o período 2017-2021, Marcelo Crivella, durante seu mandato, tem relatado interesse em criar espaços interativos e de convivência pacífica com os grafiteiros e artistas da cena urbana no Rio de Janeiro. Em 2017 autorizou ações de intervenção com grafite em alguns lugares da cidade, especialmente no Centro. "O grafite se integrou à cultura do Rio. É muito importante que, em propriedades privadas, se tenha autorização. Se não, fica algo arrogante e que tira a beleza da arte. No espaço público, desde que não seja pichação, tudo bem, se incorporou à nossa cultura". (CRIVELA..., 2017).

Por outro lado, no dia 26 de fevereiro de 2018, foi promulgada a Lei no 6326, oriunda do Projeto de Lei no 2056-A de 2016, pela Câmara Municipal do Rio de Janeiro. Chamada de Pichação Zero e proposta pelo vereador Carlos Bolsonaro, a lei propõe ações para que sejam cobradas multas de acordo com os valores correspondentes à recuperação dos bens danificados. O decreto estabelece que será responsabilizado quem pichar ou, por qualquer outro meio, conspurcar edificação ou monumento, público ou privado, de acordo com o previsto na Lei no 12.408, de 25 de maio de 2011, tendo como finalidade da multa reparar o dano, que consiste em eliminar as marcas da pichação e pintar integralmente a edificação ou monumento (RIO DE JANEIRO, 2018).

Apesar dos esforços em delimitar o que está certo ou errado, na apropriação dos espaços públicos, há uma zona difusa entre a legislação e a ilegalidade. Definir técnicas, materiais, usos e apropriações no espaço urbano é tentar dominar um território infinito de possibilidades. Algumas ações, como a determinação de regras sobre o uso de tinta spray em latas, tentam controlar a venda para o uso em espaço não autorizado. A lei proíbe a venda para menores de 18 anos e o spray só pode ser vendido para maiores de idade mediante a apresentação de documento de identidade e emitindo nota fiscal em nome do comprador. No produto deve conter as frases: "Pichação é crime" e "Proibida a venda para menores de 18 anos". O comerciante que infringir a lei será punido com multa e suspensão parcial ou total das atividades (BRASIL, 2011).

Mesmo tentando estabelecer limites para a prática e o uso dos materiais relacionados ao grafite, ações como a do grafiteiro paulista Alexandre Orion, por exemplo, demonstram que até o critério de uso de tinta para a realização de manifestações artísticas no espaço urbano pode ser subvertido. Na obra Ossário, ele usou a técnica chamada de grafite reverso, na qual ao invés de aplicar tinta à superfície a ser trabalhada, ele limpou seletivamente as paredes da passagem subterrânea entre a Avenida Europa e a Avenida Cidade Jardim, em São Paulo. Uma câmera de vigilância permitiu que fosse vista a ação que o grafiteiro fazia, então, diferentes órgãos como a Guarda Civil Metropolitana e a 
Polícia Militar tentaram frear o trabalho do artista, que se defendeu explicando que ele não estava pintando e sim limpando as paredes dos túneis, pretas pela poluição causada pela fumaça dos carros a diesel. Para eliminar as imagens das caveiras de Orion, o estado preocupou-se com o que não tinha feito antes: mandou lavar os painéis, desfazendo a obra de arte, que visível se manifestava sobre a morte invisível. "Arte é sujeira, poluição não o é" (MARTINS, 2018).

Figura 1 - Alexandre Orión, Ossários. Grafite reverso, túneis da Av. Europa e a Av. Cidade Jardim, São Paulo, 2006.

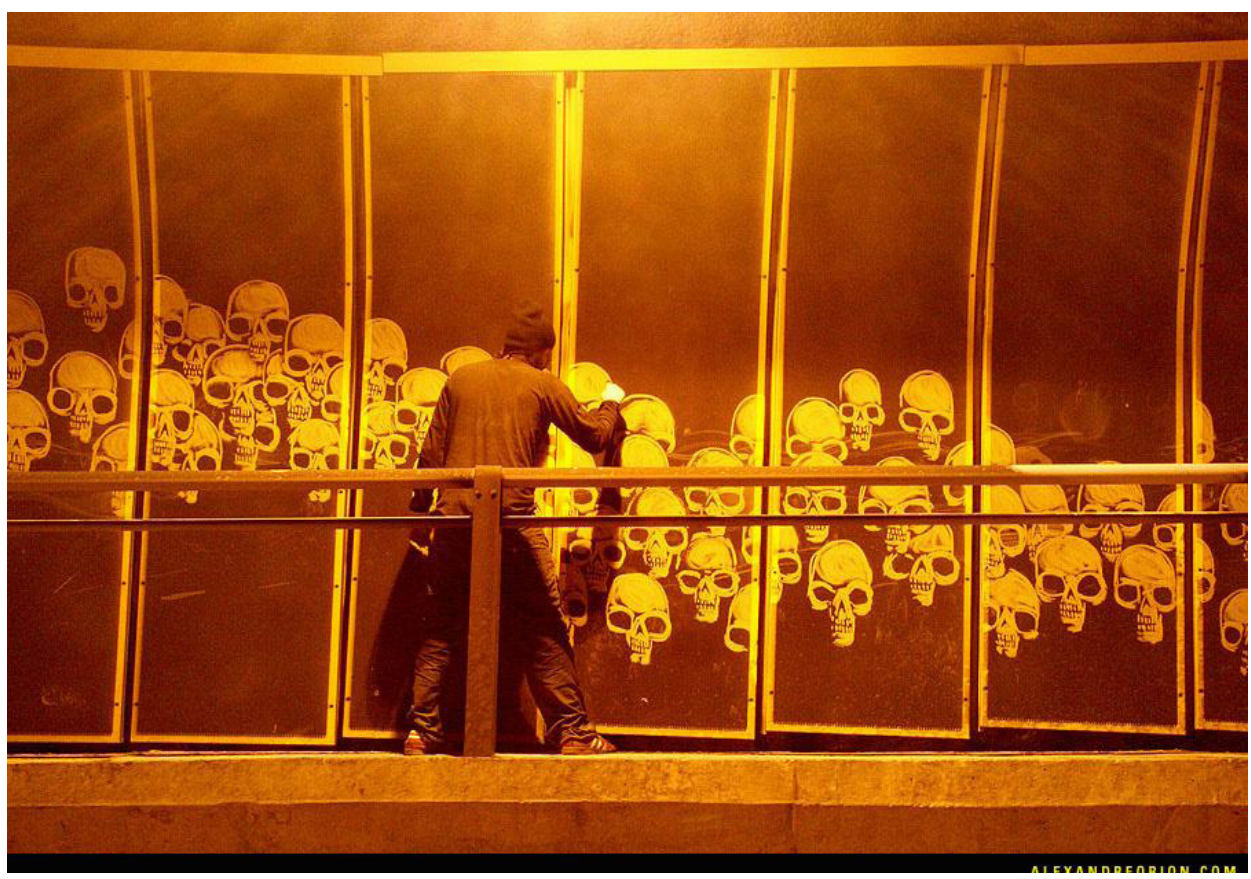

Fonte: Martins (2018).

Artistas de rua, pichadores e grafiteiros têm um ponto de vista em comum: concebem a rua como cenário coletivo e democrático, acessível para todos, e por isso defendem a sua expressão como prática autêntica dentro desse espaço. Porém, as leituras realizadas pelos habitantes da cidade diferem muito em relação a sua prática, alguns espaços da cidade são considerados depredados e vandalizados quando pintados de maneira aleatória com assinaturas, palavras ou rascunhos que parecem não se importar com a estética do resultado. "Diferentemente dos grafiteiros, os pichadores ainda são, como se vê, considerados, em qualquer situação, criminosos que, além de sujar a cidade com seus 'pichos' de difícil compreensão, representam uma parcela marginalizada não só pela sociedade, mas também pela lei penal. Além de possuir evidente caráter discriminatório, a referida alteração legislativa, ao buscar diferenciar a arte do vandalismo, se contradiz, na medida em que apenas o grafite previamente autorizado ou consentido é lícito, enquanto o outro por mais colorido e bem feito que seja -, é tido como criminoso pela simples ausência de autorização" (BURG; BRUSAMOLIN, 2017). 


\section{A QUESTÃO DA PESQUISA}

Os conflitos na aceitação dessa expressão, especialmente nos casos em que não é autorizado, coloca um desafio na compreensão dessa diversidade de representações e funcionalidades. No Rio de Janeiro, como em outras cidades, personagens destacados da cena do grafite têm feito com que seus trabalhos tenham um valor além da simples apropriação dos espaços públicos, alguns convertendo-se em símbolos e referências na identidade da cidade, outros, usando-o como ferramenta para transformar lugares marginalizados. Muitos grafiteiros têm feito esforços por agregar valor ao grafite, para mudar a percepção ruim que possa ter dentro da sociedade, trabalhando por criar caminhos para melhorar a aceitação da prática. Outros tentam se valer justo de sua força subversiva para ressaltar sua função de denúncia e combate. Então, de que maneira a aparição de pichações e grafites influencia a identidade dos espaços urbanos? O grafite é uma linguagem, uma forma de comunicação que tem, tanto nas origens, como nas práticas contemporâneas uma miríade de experiências difíceis de serem enquadradas em critérios muito dicotômicos como propõe a atual legislação nacional.

Geralmente, grafiteiros e pichadores procuram lugares que sejam amplamente observados e transitados, onde possam atingir a maior quantidade possível de olhares em função do conteúdo do suporte grafitado, assim, o objetivo de comunicar uma ideia (seja esta qual for) alcançará o máximo possível de espectadores. Em busca de um espaço de aceitação dentro da sociedade, o grafite tem procurado se posicionar também como um meio de interação e mudanças urbanísticas positivas, sendo usado, por exemplo, como uma ferramenta para a revitalização de áreas marginalizadas. Dado que os limites são difusos, e que é difícil estabelecer um conjunto de normas técnicas para enquadrar os diferentes tipos de intervenções urbanas, tomamos alguns exemplos de grafites da cidade do Rio de Janeiro, numa tentativa de classificação dentro de dois eixos principais: o caráter legal e o caráter comercial do grafite. Apresentamos aqui as obras escolhidas.

\section{ALGUNS CASOS EXEMPLARES DA CIDADE DO RIO DE JANEIRO}

Os casos usados nesta amostra destacam-se por ter ganho um espaço dentro da memória social-coletiva, além de sobressaírem pela diversidade de enquadramentos propostos pela questão da pesquisa. Os casos apontados aqui servem de exemplo de como são diversas as opiniões e julgamentos sobre o grafite e as intervenções dos espaços urbanos e como elas não são estanques - tanto que muitos dos grafiteiros e artistas de rua que hoje em dia são reconhecidos, começaram fazendo seus trabalhos de forma livre e não autorizada, pelos muros do espaço público. 
Um dos casos que mais ganha destaque é o trabalho de José Datrino - o profeta Gentileza - que nas décadas de 70 e 80 pregava suas crenças escrevendo suas preces pelos muros da capital fluminense. $O$ universo do poeta Gentileza tem uma estrutura simbólica, uma conformação ético-religiosa e uma visão do mundo que convida a enxergar os valores, a se conhecer a si mesmo e a reconhecer as atitudes que fazem o melhor caminho para se relacionar com os outros. Mesmo sem ser reconhecido exatamente como um grafiteiro ou pichador, ele criou sua própria grafia e desenhava as palavras geralmente nas cores verde, amarelo, azul e vermelho. Seu legado pode ser visto no quilômetro 1 da Avenida Brasil, como um portal de entrada da cidade reconhecido pelos cariocas, e considerado parte da identidade do Rio de Janeiro. No ano de 1997 as pinturas foram apagadas como forma de condenação de sua expressão, considerada grafite, e apenas em 2000, graças ao trabalho do professor Leonardo Guelman (2008), da Universidade Federal Fluminense, e outros colaboradores, tem sido resgatada boa parte da história deste personagem icónico e do seu trabalho. Foram restaurados 56 dos seus escritos nas pilastras do viaduto do Caju, pelo projeto Rio com Gentileza, e tombados como patrimônio da cidade, reconhecendo o valor artístico, documental e sociológico dos murais. Parte do Viaduto foi demolido por contas das reformas dessa região, mas foram mantidos os pilares que abrigavam os escritos do Profeta. As intervenções que quando feitas não tinham permissão legal, hoje constituem uma parte valiosa da gráfica urbana dos cariocas.

Figura 2 - Textos do poeta Gentileza, nas pilastras do Viaduto do Caju, depois da restauração. Rio de Janeiro, 2000.

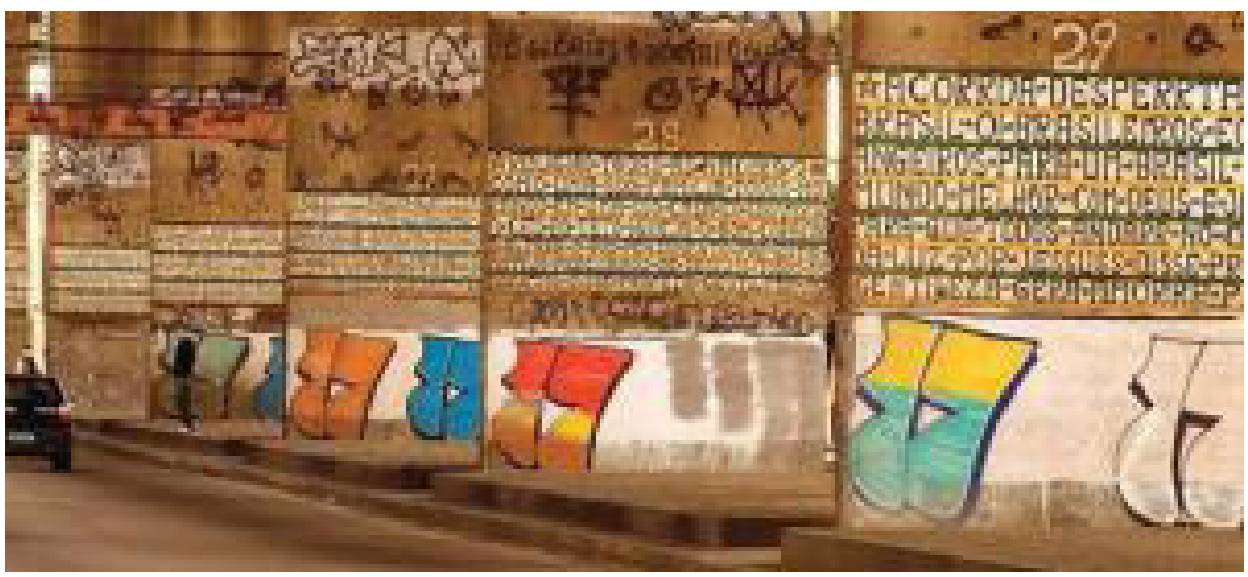

Fonte: Cândida (2011).

Também nos anos 80, a frase "CELACANTO PROVOCA MAREMOTO" aparecia pelos muros de Ipanema, no Rio de Janeiro. O texto era circundado por uma moldura com uma seta, que caía em uma gota tremendo, com dois tracinhos ao lado. O autor era o jornalista Carlos Alberto Teixeira, o C@l, que só saiu à luz pública logo depois que outras pessoas tentarem se apresentar como autores do grafite. A frase criou toda classe de suposições como a de ser um ato referente à política, ao tráfico e ações ilegais. Mas ele contou que a origem da frase foi do seriado chamado National Kid, exibido na década de 1960, onde 
um dos episódios era sobre os seres abissais, e um deles era o peixe chamado celacanto. Um dos personagens maléficos, o Dr. Sanada, dizia: "Celacanto provoca maremoto". E não provocava nada, quem provocava era um submarino chamado Guilton (CRIS K, 2003). Diz o autor:

Eu pichava só tapume e parede [...] Eu só pegava lugares escolhidos a dedo, como na 'saída' de curvas, por exemplo: quando o cara saía da curva de São Conrado, lá na Barra, dava de cara com uma casa onde tinha a inscrição do Celacanto bem no centro, o que causava uma impressão boa. Agora, qual o motivo disso aí? No meu caso, eu acho que sempre tive uma ânsia por comunicação, por passar uma mensagem, e o Celacanto foi isso. (CRIS K, 2003).

Figura 3 - Carlos Alberto Teixeira e o grafite Celacanto provoca maremoto. Rio de Janeiro, 2006.

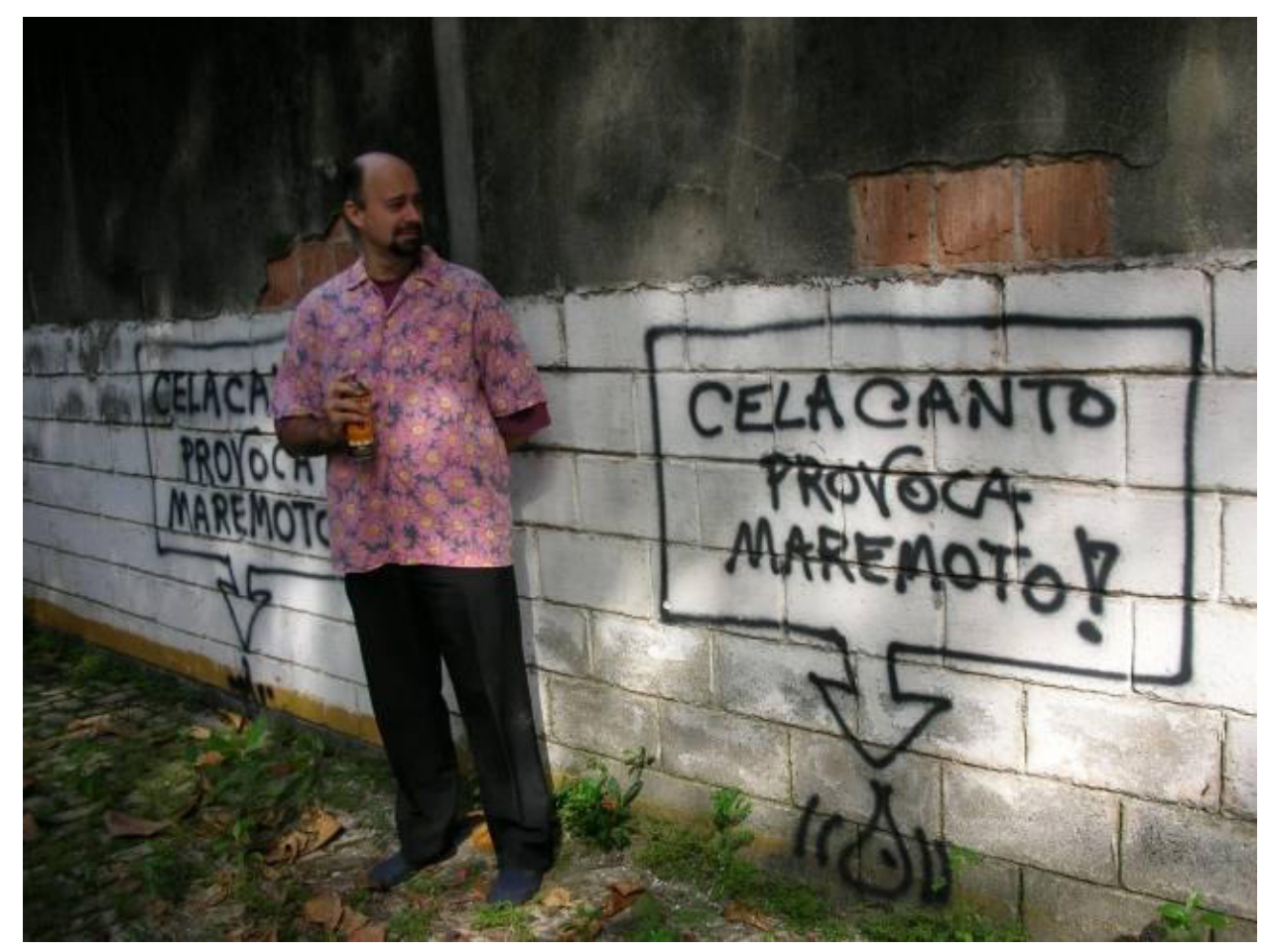

Fonte: CRIS K. (2003).

Pelos anos 1990, a jovem Joana Cesar, apropriou-se dos muros da Zona Sul convertendo-os nas páginas do seu diário. Quando criança, teve a necessidade de inventar um alfabeto para seu irmão mais velho não entender, para poder escrever à vontade e, assim, manter em segredo seus sentimentos e pensamentos. Anos depois, ingressou na Escola de Artes do Parque Lage, e no atelier da mãe trabalhava tentando misturar os aprendizados com suas ideias. Descobriu-se no ato de cobrir a parede de tinta quando precisava "limpar" o espaço para ter de novo sua tela disponível e foi ali que encontrou a importância e a necessidade de apagar aquilo que construía, fazendo com que seu trabalho se fizesse e desfizesse, que sumisse e se escondesse. "Descobri que tinha mais 
tesão em cobrir do que em pintar", explicou. "Escrevia por toda a parede, muito solta, sabendo que teria depois a sensação maravilhosa de cobrir tudo aquilo." (ESTEVES, 2012). Usando o efêmero como componente dentro do processo criativo, Joana começou a escrever nas ruas seus pensamentos, desejos, angústias, confissões e frustrações. Converteu o Rio de Janeiro num caderno, mostrando seus escritos na cara da sociedade e mantendo-os ao mesmo tempo ocultos, graças ao código criado. "Ela quer gritar para o mundo, mas não quer ser ouvida", "É um grito mudo", diz Paulo Orenstein, matemático da PUC Rio, que trabalhou num algoritmo para decifrar o código da Joana, como um desafio de programação dentro dos estudos. (ESTEVES, 2012).

Figura 4 - Trabalho de Joana Cesar, para a II Bienal Mundial da Criatividade. Rio de Janeiro, 2012.

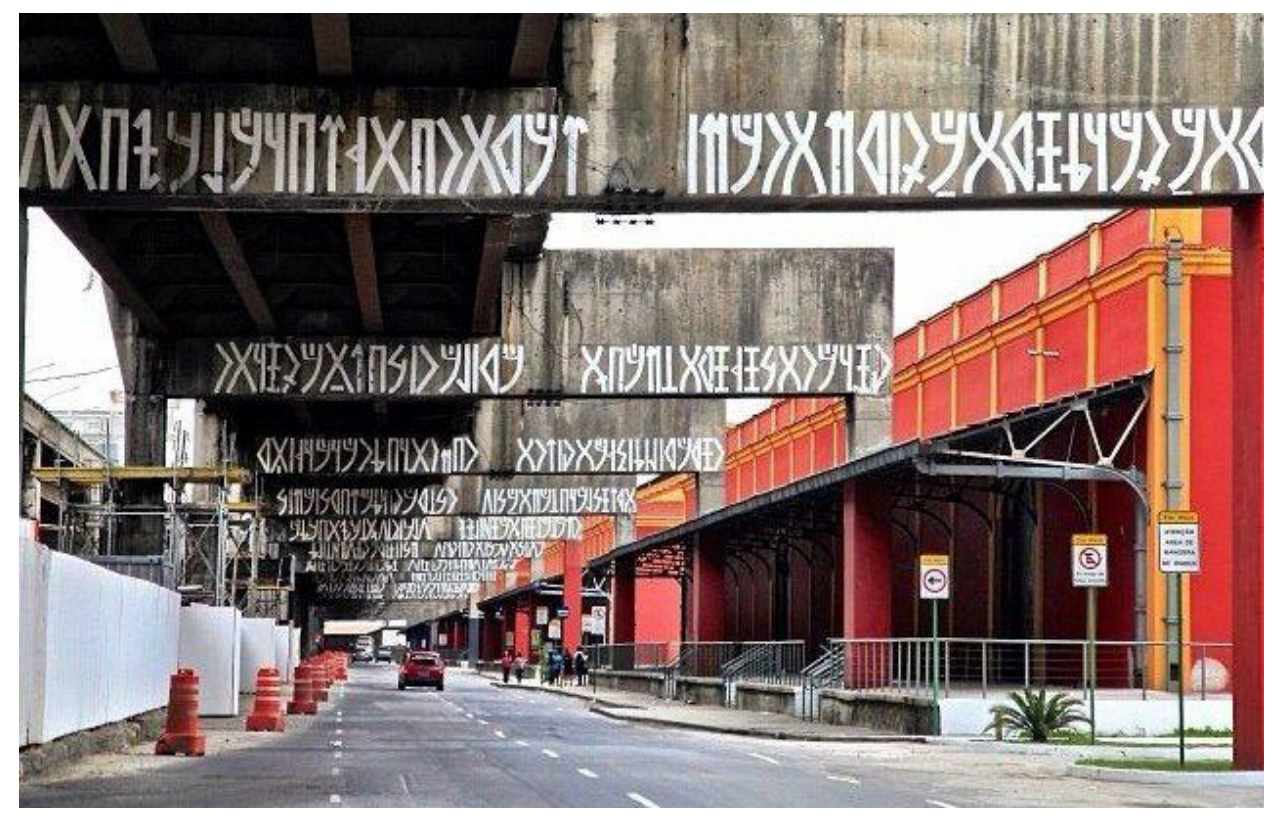

Fonte: Usina (2014).

Outras ações de apropriação do espaço público transmitem mensagens que mexem com a percepção do status, segurança, cuidado e limpeza de um lugar. Isso acontece com a pichação, considerada como o ato de fazer assinaturas e símbolos no espaço citadino (tags), de forma subversiva. O picho é feito para incomodar, para aparecer, como um protesto instintivo, como resposta à violências sociais e exclusões as quais o pichador recebe da sociedade. Sendo feito sob nenhuma regra ou limitação, é livre, mas ilegal. A pichação é a expressão de grupos que se sentem marginalizados e excluídos, se apropriando da cidade como se fosse uma folha em branco disponível para desenhar códigos que não são feitos para a sociedade entender, nem para ser "bonitinho" e sim para ter um espaço dentro da comunidade da pichação. As primeiras pichações feitas no Rio de Janeiro foram as políticas, contra a ditadura, como uma forma de protesto contra a repressão da época, depois passou a ser um recurso expressivo com intenções. Um exemplo dessa relação entre denúncia política e intervenção ilegal a um símbolo público foram as pichações na Câmara dos Vereadores do Rio de Janeiro como forma de protesto pelo 
assassinato da vereadora Marielle Franco (14/03/2018). Nesse caso, ao invés dos textos ilegíveis, aqui o conteúdo é fundamental.

Figura 5 - Pichações realizadas na Câmara Municipal do Rio de Janeiro, durante a manifestação pelo assassinato de Marielle Franco. Rio de Janeiro, 2018.

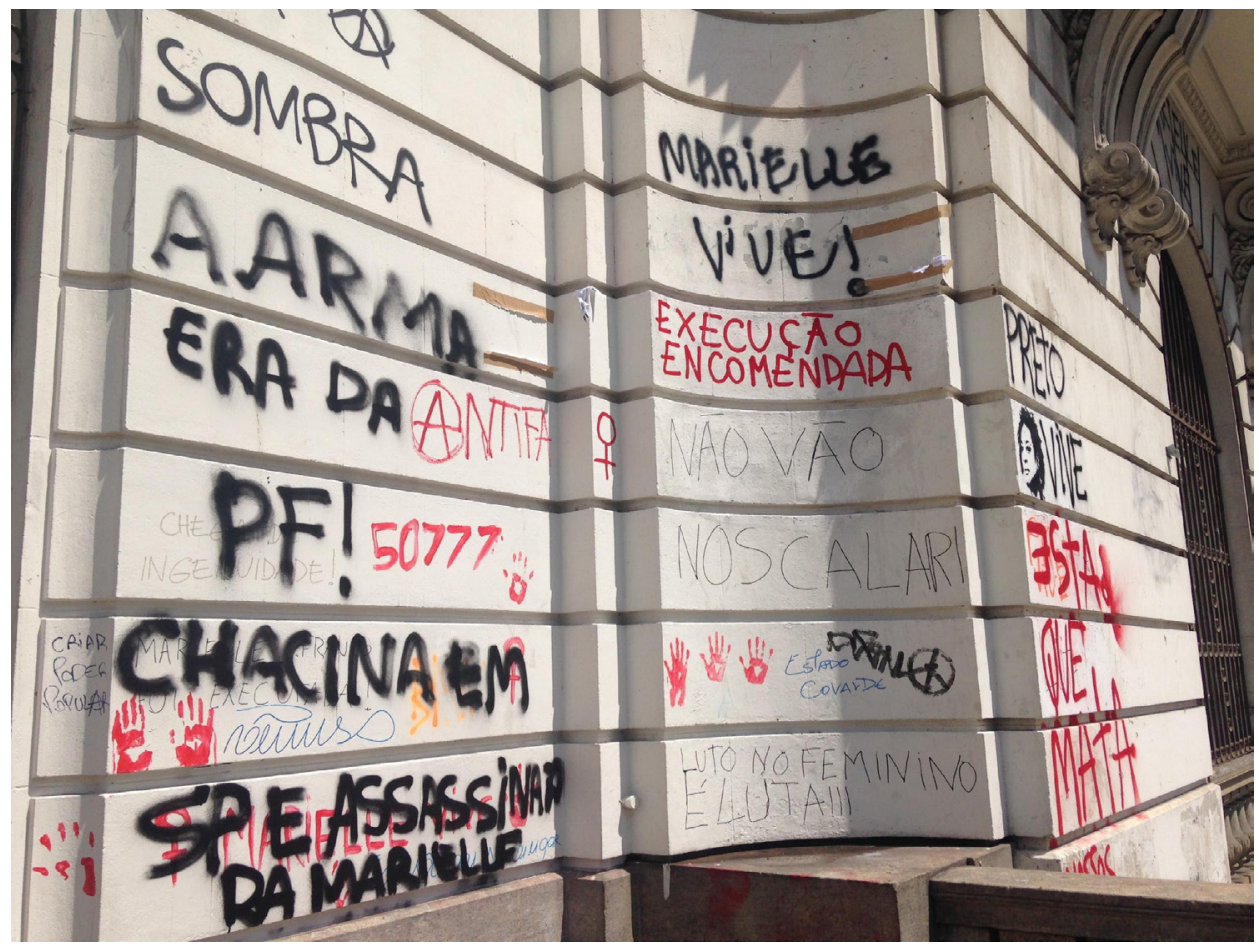

Fonte: Arquivo pessoal.

Já outras ações feitas de maneira ilegal, mas com fins comerciais, (não consideradas grafites e sim intervenções com propósito comercial) são realizadas nos muros de espaços geralmente suburbanos com alto fluxo de veículos, para publicidade de serviços informais diversos, como venda de artigos, serviços de transporte e serviços religiosos.

Figura 6 - Painel publicitário pintado manualmente. Zona Norte do Rio de Janeiro, 2018.

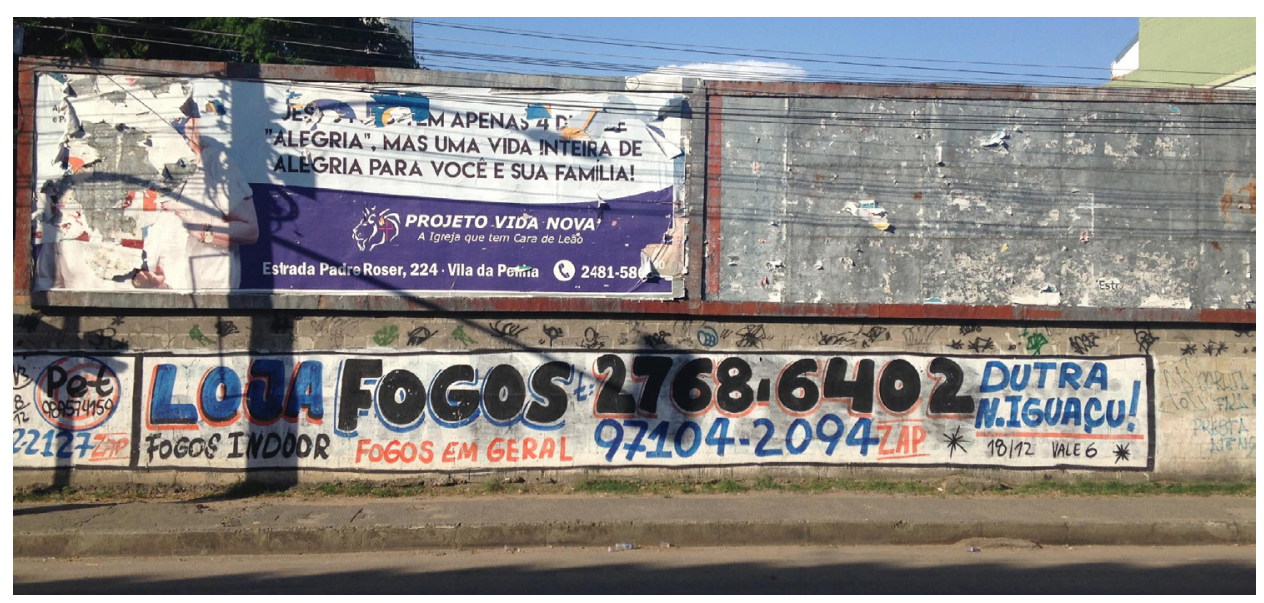

Fonte: Arquivo pessoal. 
Paralelo às práticas descritas, grafiteiros são contratados para realizar trabalhos patrocinados por entidades públicas e privadas, para a revitalização e ressignificação de espaços. A prática valoriza os lugares onde é aplicado além de ressignificar áreas marginalizadas, o que contribui para a recuperação, revitalização e valorização de comunidades e espaços degradados. Dessa forma, ao deixar de ser pinturas que sujam as fachadas, passam a se converter em símbolos de cultura, lazer e aproveitamento para o empoderamento de uma comunidade, ganhando assim a aceitação na visão coletiva da sociedade.

No Rio de Janeiro, projetos como o Museu de Favela no Morro do Cantagalo, na Zona Sul da cidade, tem dado visualização e relevância para a comunidade. O projeto que começou em 2009, liderado pelo grafiteiro Acme (nascido e criado nesse lugar), teve como princípio a ideia de criar o circuito das casas-tela como uma forma de integrar a arte de rua ao cotidiano dos moradores, consequência disso foi o surgimento de um roteiro atrativo para turistas e visitantes, envolvendo a moradores, artistas e promotores culturais. O MUF tem sido um exemplo para outros lugares que buscam opções para a renovação de espaços marginados e esquecidos pela sociedade. Nesse sentido a arte do grafite se expressa através de ruas e espaços públicos, os artistas da comunidade se unem, contribuindo com obras que representam a luta a favor de dignidade, representatividade e melhoria das condições sociais desse território (SILVA; PINTO; LOUREIRO, 2012).

Figura 7 - Um dos grafites do MUF, no Morro do Cantagalo. Foto por André Gomes de Melo, 2016.

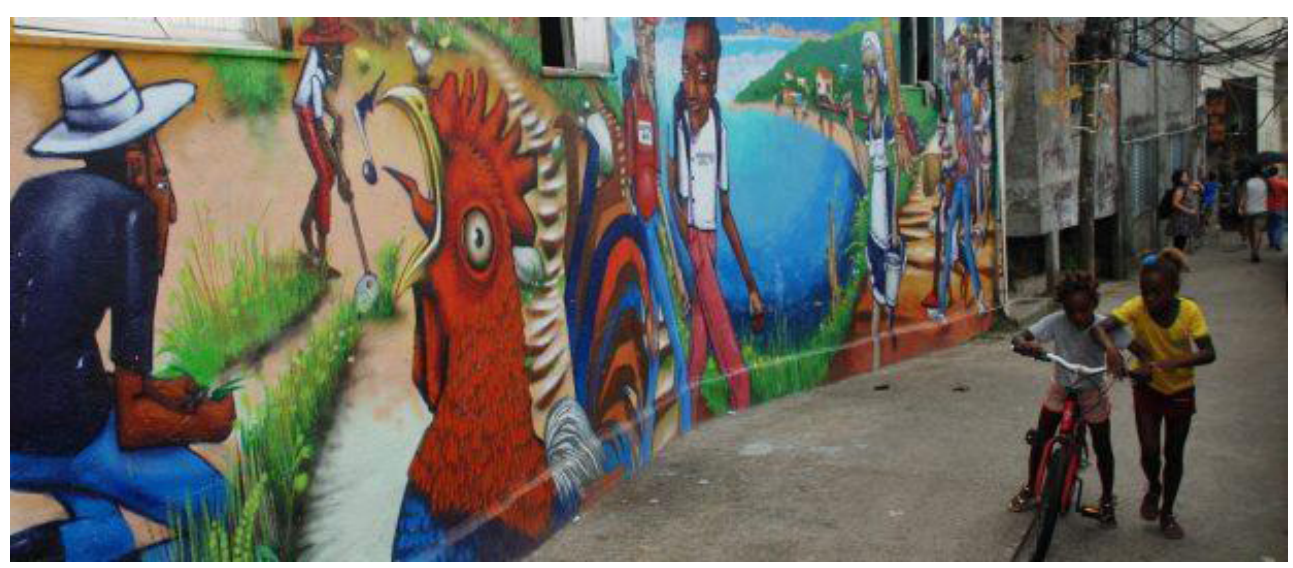

Fonte: Mackay (2016).

No Centro da cidade, a Galeria Providência, que começou em 2017, propõe também a transformação de áreas marginalizadas em espaços transitáveis, agradáveis e acessíveis para todos. Graças ao trabalho de moradores, gestores culturais e grafiteiros que correram atrás de recursos na própria comunidade, o Morro da Providência foi transformado em um museu a céu aberto, com visual diferenciado, que eleva a autoestima dos moradores, aproximando turistas e residentes da cidade para valorizar a comunidade, criando oportunidades de turismo e reconhecimento para a região, a partir da arte de rua (MUSEU DE ARTE DO RIO, 2017). 
Figura 8 - Galeria Providência, no Morro da Providência. Foto por Agnaldo Santana.

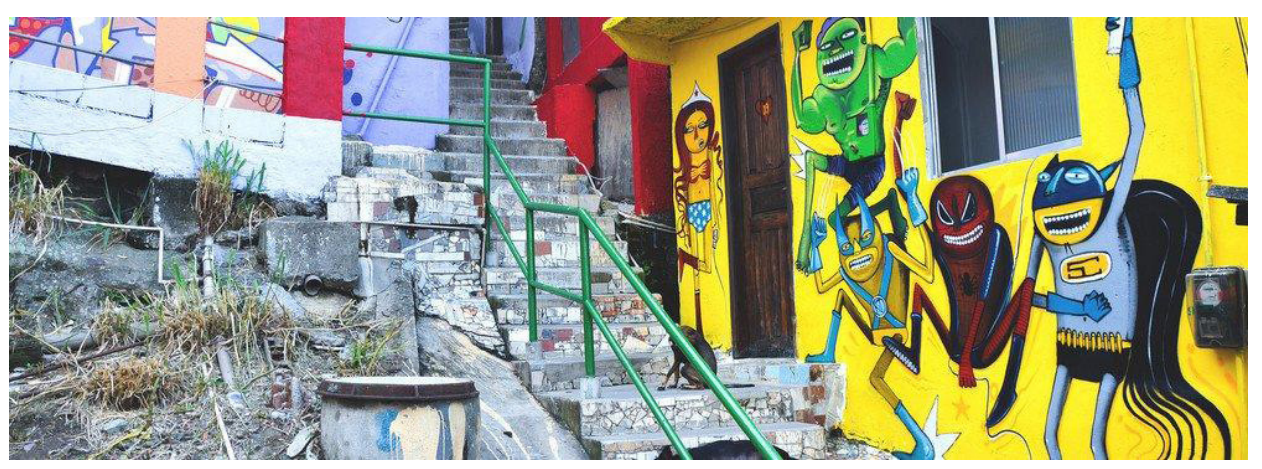

Fonte: Batista (2015).

Na Praça Mauá, a perimetral, que fazia parte da zona portuária do Rio de Janeiro (e que abrigou em seus pilares os escritos do Profeta Gentileza), foi derrubada para dar lugar ao Boulevard Olímpico. Além do recondicionamento arquitetônico do lugar, grandes pinturas nos muros na frente dos píeres foram realizadas por reconhecidos artistas de rua - o que proporcionou ao lugar o ganho de cores, reconhecimento e destaque como museu a céu aberto.

Figura 9 - Mural do artista Kobra, no Bulevar Olímpico, zona portuária do Rio de Janeiro. Foto do artista

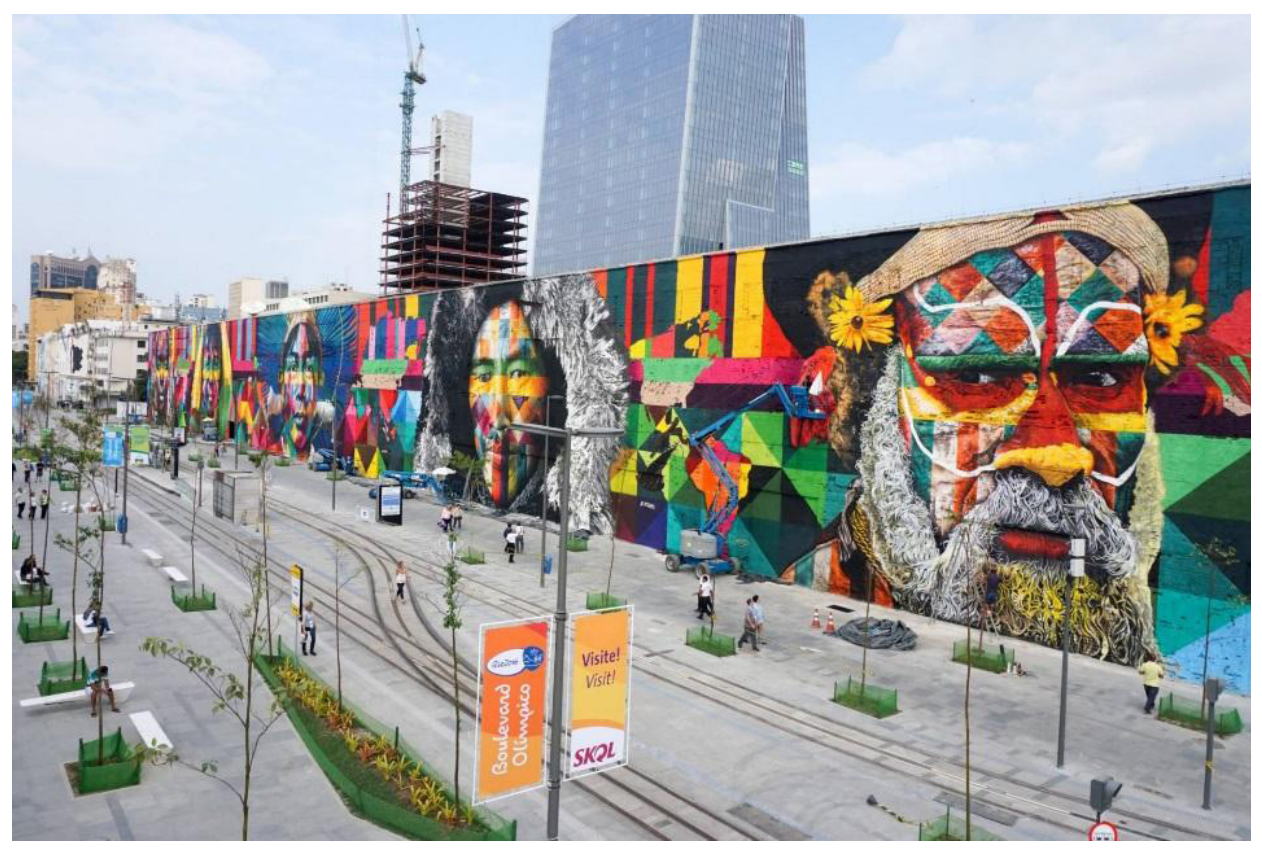

Fonte: Kobra (2018).

O trabalho de Luna Buschinelli na Escola Municipal Rivadávia Corrêa, no Centro da cidade, para o projeto Rio Big Walls, proposto pela prefeitura do Rio de Janeiro em 2017, é outro exemplo dessa parceria entre projeto urbanístico e o grafite. A artista foi convidada pelo produtor Pagu, ao lado de Andrea Franco, pelos murais pintados no Boulevard Olímpico. O projeto foi financiado com o apoio das empresas privadas RUA - Arte Urbana, Mills e Coral. (GAYOSO, 2017). 
Figura 10 - Escola Municipal Rivadávia Corrêa, por Luna Buschinelli, para o projeto Rio Big Walls. Rio de Janeiro, 2017.

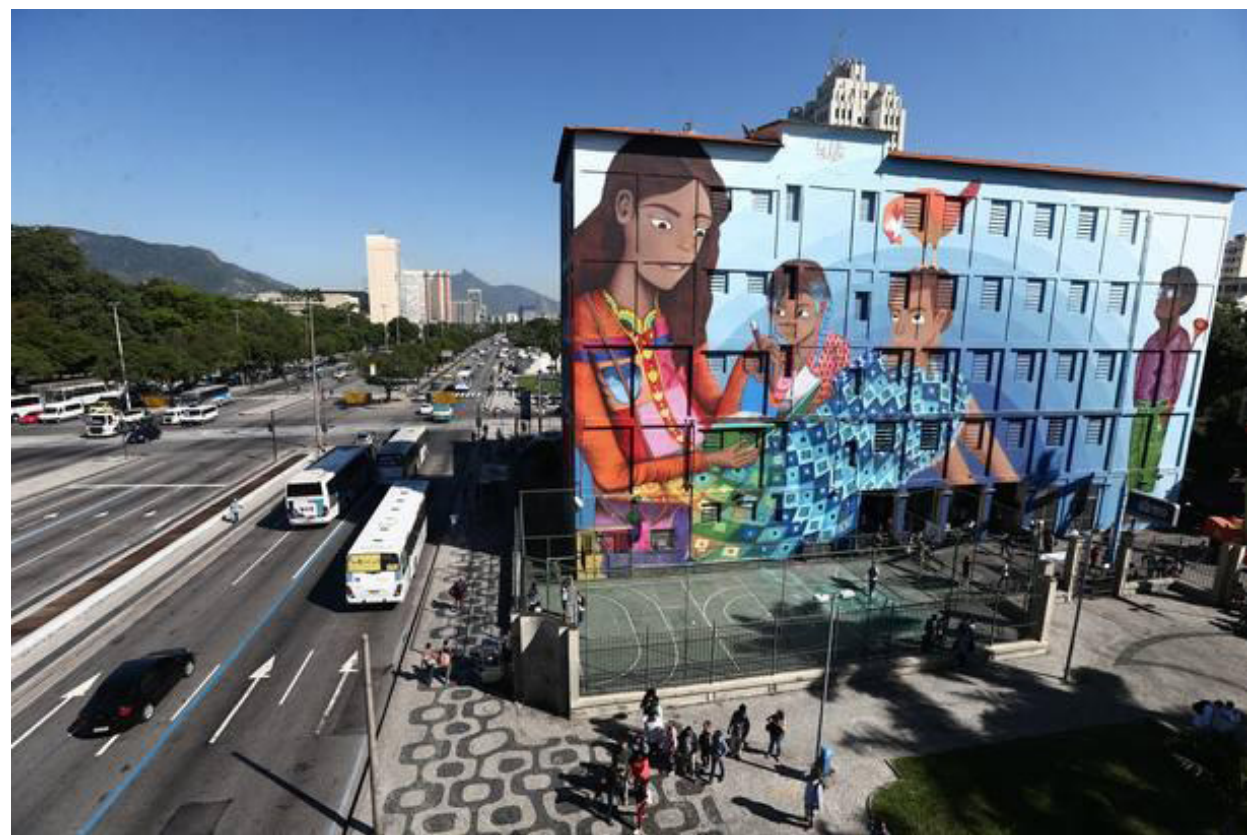

Fonte: Gayoso (2017)

Dentro do espaço privado, o grafite também é usado atualmente para outras finalidades como decoração ou veiculado em produtos, em que é aplicado de maneira legal e comercial, por meio de contratos com entidades privadas. Mesmo considerando que o grafite perde sua qualidade de grafite quando é autorizado, a aplicação dessa expressão artística é uma forma de trabalho que atende uma demanda e se transforma em produto. Destacamos como exemplo o trabalho de Marcelo Eco para a agência digital Fullpack do Rio de Janeiro, e o trabalho de Rafo Castro para o Arena Arpoador Hotel, como exemplos do grafite na decoração de espaços em ambientes privados.

Figura 11 - Mural decorativo para a agência digital Fullpack, por Marcelo Eco. Rio de Janeiro, 2018.

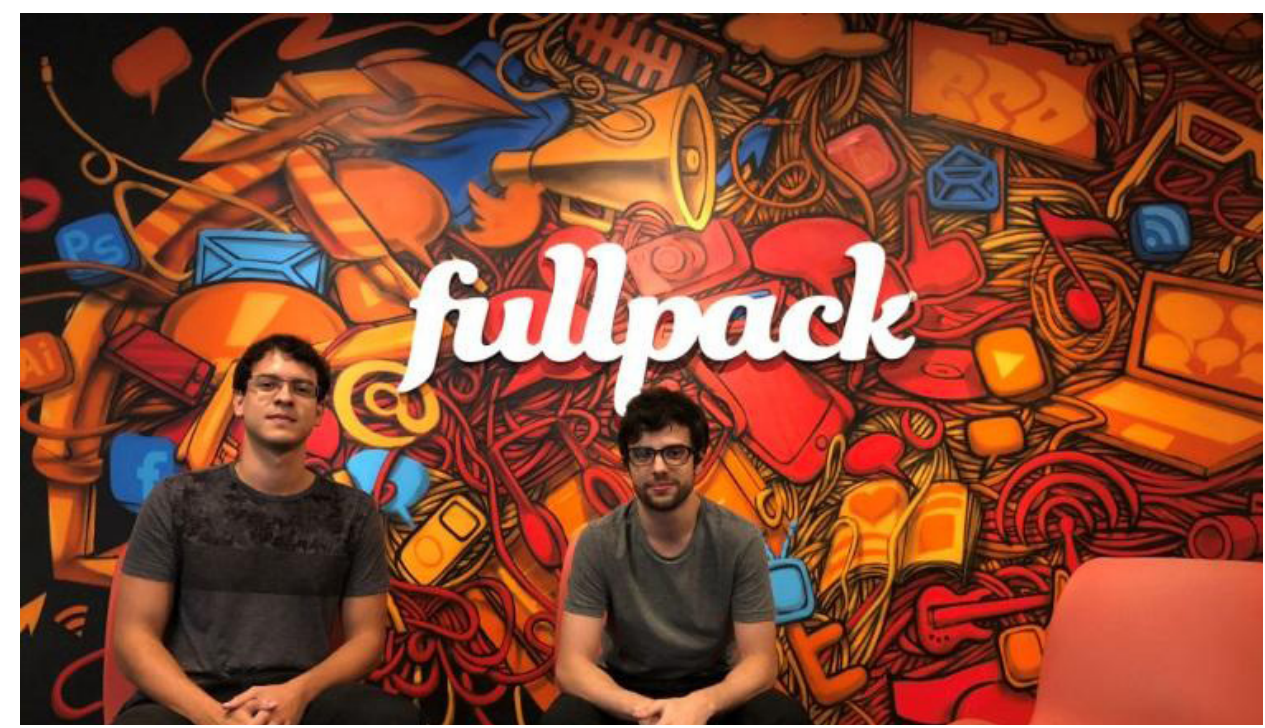

Fonte: Clube de Criação (2018). 


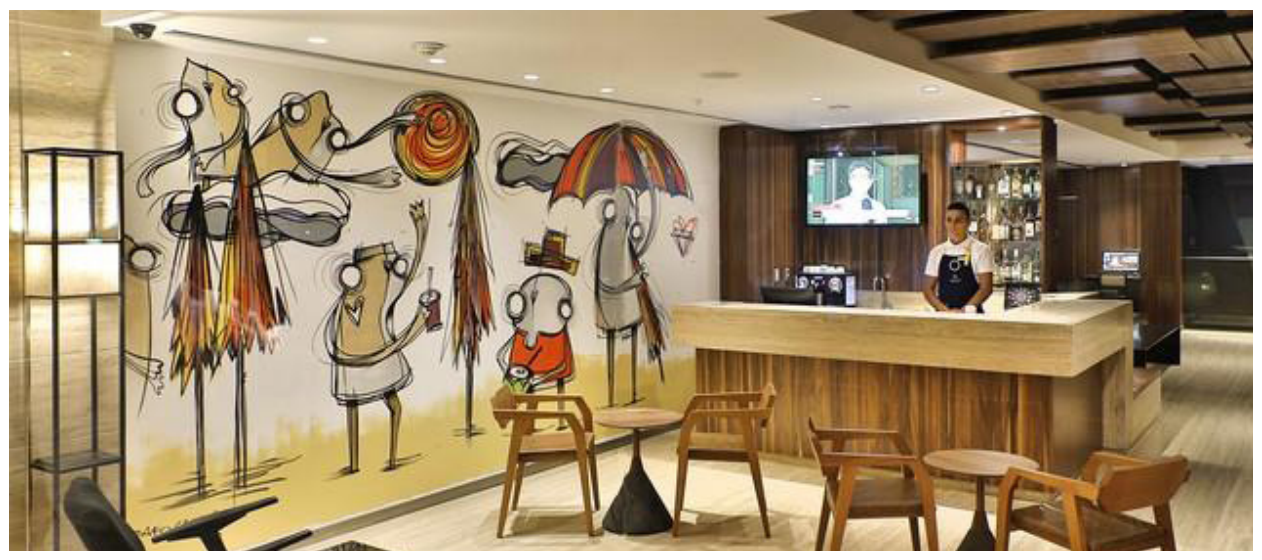

Fonte: Em busca... (2017).

\section{DOIS EIXOS E UMA REFERÊNCIA PARA ESCALAS DE VISIBILIDADE}

Para estudar os casos selecionados da pesquisa, elaboramos um quadro a partir de dois eixos: o eixo comercial e o eixo legal e, depois, os situamos num gráfico. A avaliação é feita de 0 a 4 pontos, tal escala não deve ser entendida como um juízo de valor, mas apenas como uma representação dos critérios vigentes de forma desdobrada. O máximo nível de legalidade será dado para aqueles projetos que estão tombados por órgãos públicos e o mínimo, como determina a lei, será para aquelas ações que prejudicam o patrimônio público. No comercial, a maior pontuação é para projetos com fim de divulgação de produtos e com remuneração privada, e, na menor pontuação, estão os trabalhos sem fim lucrativos, sem apoio financeiro e com funções prioritariamente lúdicas, políticas, ideológicas ou expressivas. Para entender melhor os critérios, segue uma descrição sucinta dos níveis estabelecidos a partir de uma primeira amostragem piloto confrontada com a legislação e os referenciais teóricos.

Quadro 1 - Eixo ilegal-legal de critérios sobre o grafite.

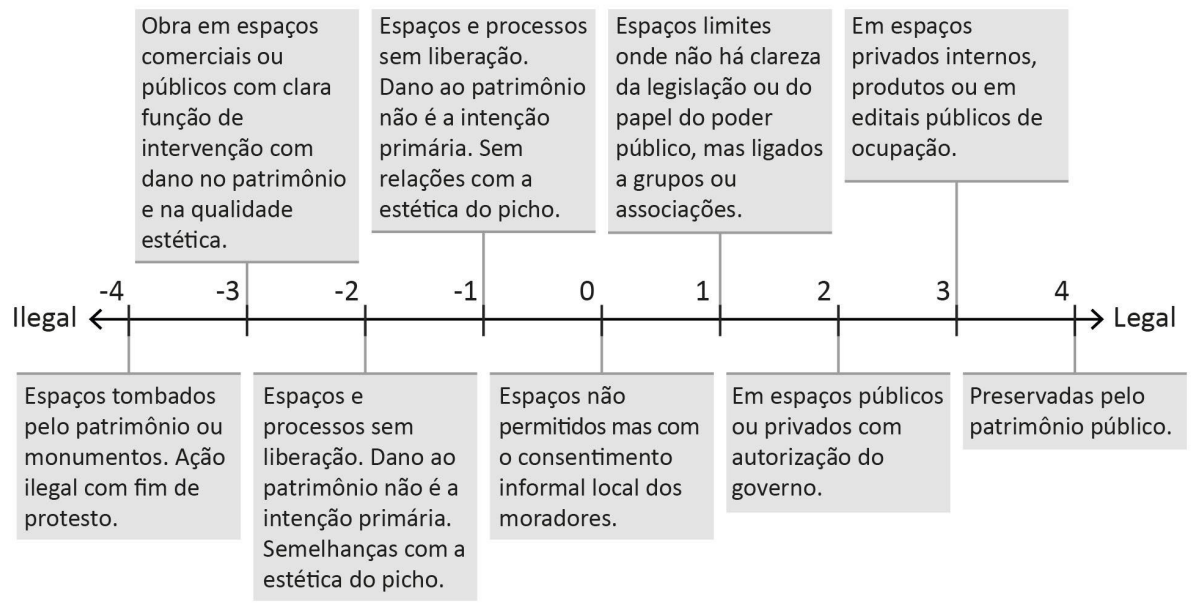

Fonte: Autores. 
Quadro 2 - Eixo comercial-não comercial de critérios sobre o grafite.

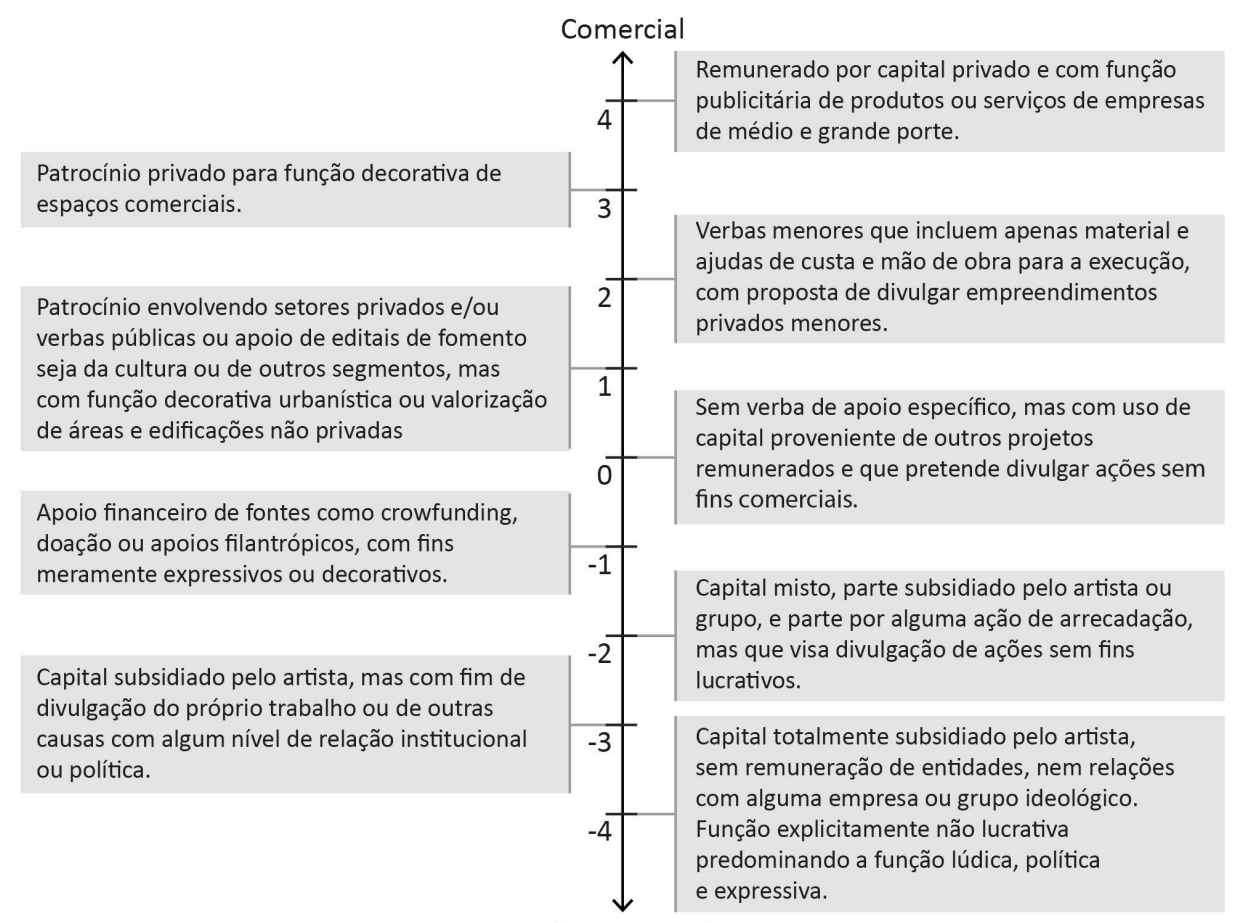

Fonte: Autores.

Podemos entender que o capital, ainda que proveniente de editais ou galerias de arte, não retira a produção do quadrante comercial, diminui o impacto em sua numeração, mas ainda o mantemos vinculado a este tipo de intenção para diferenciar o outro grupo sem apoio de nenhuma ordem, como mostrado nos quadros 1 e 2 .

O interesse da observação dos quadros apresentados é que não só podemos ver dados quantitativos de determinadas posições (como a menor concentração nos quadrantes ilegal/comercial ou no legal/não comercial indicando uma associação frequente entre as ações comerciais e legais), mas que também podemos apontar situações que no decorrer do tempo mudam a sua posição no gráfico (quadro 3). Algumas obras saem da ilegalidade e vão para a posição que é, por exemplo, mais aprovada socialmente. Colocando nossa amostragem nesta pontuação, encontramos a seguinte visualização.

\section{CONCLUSÃO}

A legitimação do grafite é mais um mito da sociedade, que cria juízos de valor dependendo do custo que possa ter um objeto, nesse casso, o grafite como pintura, ou de como se deu sua permissão pelo estado ou pelo setor privado. "Cada objeto do mundo pode passar de uma existência fechada, muda, a um estado oral, aberto à apropriação da sociedade, pois nenhuma lei, natural ou não, pode impedir-nos de falar das coisas" (BARTHES, 2003, p. 131). 
Quadro 3 - Avaliação de ações relacionadas ao grafite.

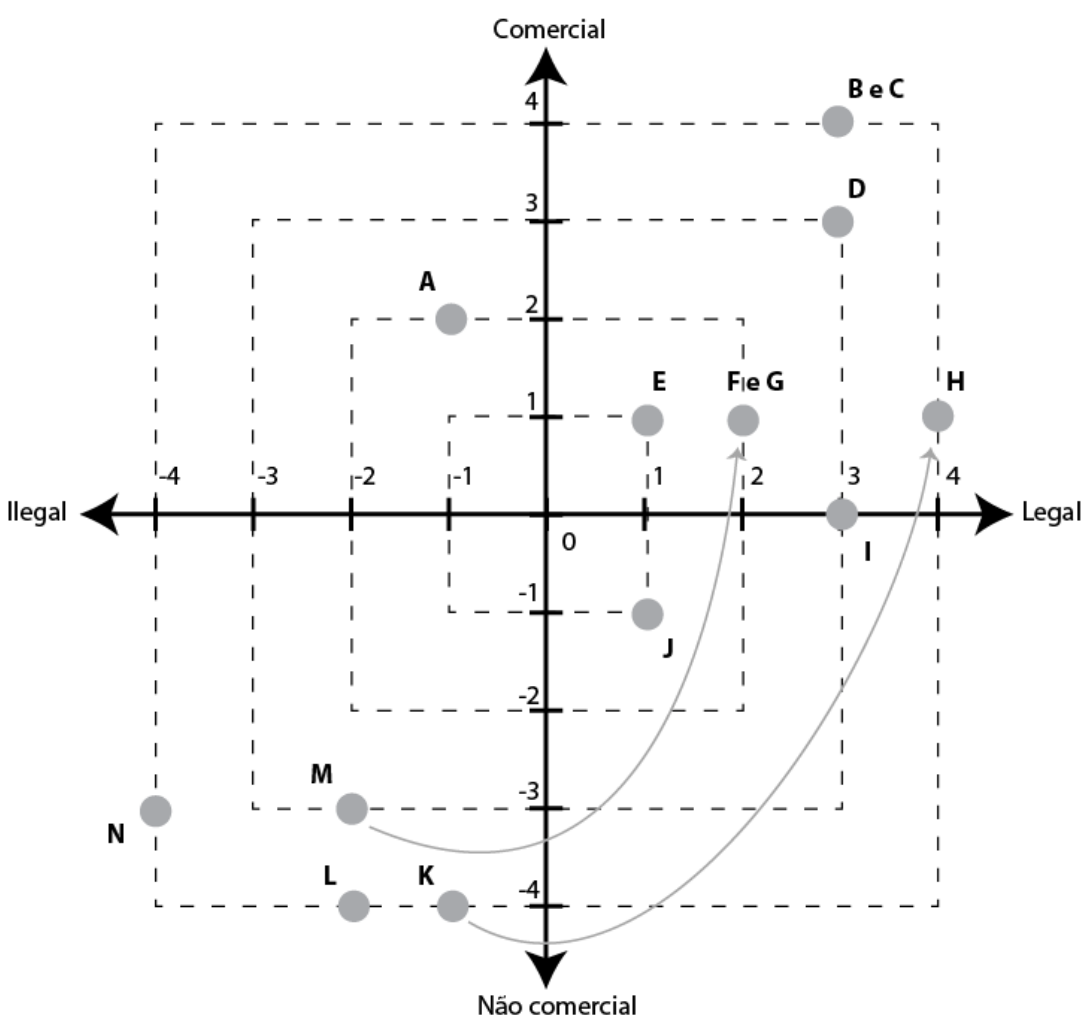

\begin{tabular}{|c|c|c|c|}
\hline Ilegal - Comercial & Comercial - Legal & $\begin{array}{l}\text { Legal - Não } \\
\text { Comercial }\end{array}$ & $\begin{array}{l}\text { Não Comercial - } \\
\text { Legal }\end{array}$ \\
\hline $\begin{array}{l}\text { A. Publicidade de } \\
\text { serviços informais, } \\
\text { no subúrbio da } \\
\text { cidade }\end{array}$ & $\begin{array}{l}\text { B. Capa do CD Thiaguinho, } \\
\text { por Marcelo Ment } \\
\text { C. Mural na Agência } \\
\text { Digital Fullpack, por } \\
\text { Marcelo Eco } \\
\text { D. Mural no Hotel Arena, } \\
\text { por Rafo Castro } \\
\text { E. MUF - Museu de Favela } \\
\text { F. Escritos de Joana Cesar } \\
\text { (atual) } \\
\text { G. Mural da Praça Mauá, } \\
\text { por Kobra } \\
\text { H. Murais do Profeta } \\
\text { Gentileza (atual) }\end{array}$ & $\begin{array}{l}\text { I. Escola Rivadávia } \\
\text { Correa, por Luna } \\
\text { Buschinelli } \\
\text { J. Galeria } \\
\text { Providencia }\end{array}$ & $\begin{array}{l}\text { K. Murais do Profeta } \\
\text { Gentileza (começo) } \\
\text { L. Celacanto provoca } \\
\text { maremoto, por Carlos } \\
\text { A. Teixeira } \\
\text { M. Escritos de Joana } \\
\text { Cesar (começo) } \\
\text { N. Pichação protesto } \\
\text { pela morte de } \\
\text { Marielle Franco, } \\
\text { Câmara Municipal do } \\
\text { Rio de Janeiro }\end{array}$ \\
\hline
\end{tabular}

Fonte: Autores.

A aceitação do grafite depende não só de onde e como é feito, e sim das comunidades que se colocam a favor ou contra, já que o posicionamento acontece dentro de um pensamento social coletivo.

Entre as tentativas do governo por criar regras que determinem as condições para a aplicação de grafites, está a limitação para a venda de tinta spray no Brasil. No entanto, grafiteiros e pichadores usam esse material apenas como um meio para a execução das intervenções, já que outras ferramentas e tintas também são usadas no processo; o objetivo principal é o de transmitir uma mensagem de forma livre e visível no espaço público. Muitas vezes a sociedade 
e o governo criminalizam o grafite e a pichação porque consideram que esta manifestação artística deveria ser realizada apenas com o consentimento das entidades correspondentes para valorizar o patrimônio público e privado, mas a comunidade do grafite defende a liberdade de criação que a prática precisa, sem isso no momento em que é autorizado tal manifestação perde seu sentido e se transforma em um trabalho que atende uma demanda e consequentemente se converte em produto.

Qual é a necessidade de ressignificar e se apropriar de espaços, que pertencem a todos os habitantes e transeuntes de uma localidade? A ideia de vandalismo ao invés de apropriação como forma de livre expressão continua gerando muita confusão. A linha tênue entre arte e depredação depende não só das determinações da lei mas também do imaginário coletivo, dependendo da valorização que as pinturas geram nos espaços utilizados, e o pertencimento que cria na sociedade. A construção do gráfico apresentado aqui dá visibilidade à multiplicidade de enquadramentos sociais e as demandas de um debate que vai além da dicotomia picho/grafite para dar conta de tantos processos limítrofes de legitimação. 


\section{REFERÊNCIAS}

AMARAL, Rui. Histórico do painel entre a Avenida Paulista e Dr. Arnaldo em São Paulo. 2014. Disponível em: <http://www.artbr.com.br/paulista/index. html?page=3>. Acesso em: 9 maio 2018.

BARTHES, Roland. Mitologias. Rio de Janeiro: DIFEL, 2003.

BATISTA, Soraya. Arte urbana nas favelas do Rio de Janeiro. 2015. Disponível em: <https://www.brasil247.com/pt/247/favela247/167844/Arte-urbananas-favelas-do-Rio-de-Janeiro.htm>. Acesso em: 5 abr. 2018.

BRASIL. Lei no 12.408, de 25 de maio de 2011. Altera o art. 65 da Lei no 9.605, de 12 de fevereiro de 1998, para descriminalizar o ato de grafitar, e dispõe sobre a proibição de comercialização de tintas em embalagens do tipo aerossol a menores de 18 (dezoito) anos. Disponível em: <http://www. planalto.gov.br/ccivil_03/_ato2011-2014/2011/lei/112408.htm>. Acesso em: 9 maio 2018.

BRASIL. Lei no 9.605, de 12 de fevereiro de 1998. Dispõe sobre as sanções penais e administrativas derivadas de condutas e atividades lesivas ao meio ambiente, e dá outras providências. Disponível em: <http://www.planalto.gov. br/ccivil_03/leis/L9605.htm>. Acesso em: 5 maio 2018.

BURG, Daniel A.; BRUSAMOLIN, Frederico M. A linha tênue entre arte, crime de pichação e grafitagem. 2017. Disponível em: <http://justificando. cartacapital.com.br/2017/02/02/linha-tenue-entre-arte-crime-de-pichacaoe-grafitagem/>. Acesso em: 9 maio 2018.

CANDIDA, Simone. Livro faz inventario de 570 obras de arte que enfeitam as ruas do rio. O Globo, Rio de Janeiro, 2011. Disponível em: <https://oglobo. globo.com/rio/livro-faz-inventario-de-570-obras-de-arte-que-enfeitam-asruas-do-rio-3067759>. Acesso em: 9 abr. 2018.

CLUBE DE CRIAC̣ÃO. Disponível em: <http://www.clubedecriacao.com.br/>. Acesso em: 5 maio 2018.

CRIS K. Celacanto provoca maremoto. Rio de Janeiro, 2003. Disponível em: <http://catalisando.com/goldenlist/celacanto.htm>. Acesso em: 8 abr. 2018.

CRIVELLA abre as portas do Rio para o grafite vetado por Doria. Brasil 247, Rio de Janeiro, 5 fev. 2017. Disponível em: <https://www.brasil247.com/pt/247/ rio247/278761/Crivella-abre-as-portas-do-Rio-para-o-grafite-vetado-porDoria.htm>. Acesso em: 9 maio 2018.

DAVID, Fávia. Prefeitura estabelece critérios para a prática do grafite na cidade. 2014. Disponível em: <http://www.rio.rj.gov.br/web/guest/ exibeconteudo?id=4606694>. Acesso em: 5 maio 2018.

EM BUSCA de hotel eco-friendly? Conheça o Arena Ipanema. Vogue, Rio de Janeiro, 25 jul. 2017. Disponível em: <https://vogue.globo.com/lifestyle/ noticia/2017/07/em-busca-de-hotel-eco-friendly-conheca-o-arena-ipanema. html>. Acesso em: 5 maio 2018. 
ESTEVES, Bernardo. Gritomudonomuro. Revista Piauí, São Paulo, ed. 65, fev. 2012. Disponível em: <http://piaui.folha.uol.com.br/materia/ gritomudonomuro/>. Acesso em: 5 maio 2018.

GAYOSO, Lucas. Escola carioca ganha primeiro grafite gigante do projeto 'Rio Big Walls'. Estadão, São Paulo, 17 jun. 2017. Disponível em: <http://brasil. estadao.com.br/noticias/rio-de-janeiro,escola-carioca-ganha-primeiro-grafitegigante-do-projeto-rio-big-walls,70001848959>. Acesso em: 5 maio 2018.

GUELMAN, Leonardo. Univvverrsso gentileza. Rio de Janeiro: Mundo das ideias, 2008.

KOBRA, Eduardo. Home. 2017. Disponível em: <www.eduardokobra.com/>. Acesso em: 8 maio 2018.

MACKAY, Rhona. Por toda cidade museus comunitários estão sob ameaça de remoção. 2016. Disponível em: <http://rioonwatch.org.br/?p=19239>. Acesso em: 5 maio 2018.

MARTINS, José de S. Ossário: 2006-2011: intervenção urbana realizada através da limpeza seletiva da poluição depositada nas paredes de túneis da cidade de São Paulo: a insurgência de Alexandre Orion. Disponível em: <http:// cargocollective.com/alexandreorion/OSSARIO>. Acesso em: 9 abr. 2018.

MUSEU DE ARTE DO RIO. MAR à tona: grafite em debate: Galeria Providence: parte 1. 2017. Disponível em: <https://www.youtube.com/ watch?v=DOSnbqalXe4>. Acesso em: 8 maio 2018.

RIO DE JANEIRO. Câmara Municipal. Lei no6326 de 26 de fevereiro de 2018. Cria no âmbito do município do Rio de Janeiro a Pichação Zero. Disponível em: <http://mail.camara.rj.gov.br/APL/Legislativos/contlei. nsf/7cb7d306c2b748cb0325796000610ad8/721a263102f0bd458325823d 006df6ba? OpenDocument>. Acesso em: 5 maio 2018.

RIO DE JANEIRO. Câmara Municipal. Projeto de Lei no 268/2013.

Dispõe sobre a arte em grafite no âmbito do município do Rio de Janeiro. Disponível em: <http://mail.camara.rj.gov.br/APL/Legislativos/scpro1720. nsf/0/832580830061F31803257B7300614567?OpenDocument>. Acesso em: 5 maio 2018.

SILVA, Carlos E. Gomes; PINTO, Rita de C. Santos; LOUREIRO, Katia A. Silva. Circuito das casas-tela, caminhos de vida no museu de favela. Rio de Janeiro: Museu de Favela, 2012.

USINA. Entrevista com Joana Cesar. 2014. Disponível em: <https:// revistausina.com/2014/08/16/entrevista-com-joana-cesar/>. Acesso em: 7 abr. 2018. 